\title{
NOTES ON LEPROSY IN ADEN
}

\author{
by A. L. Fawdry, M.A., M.D., (CANTAB.) \\ Pathologist, Aden
}

The visit of Dr. R. G. Cochrane to Aden in 1955 stimulated an attempt to see whether more could be done for sufferers from leprosy in Aden Colony. There had been before the last war a small leprosy hospital managed by the Church of Scotland Mission Hospital, holding about 30 men and half a dozen women: but in the early war years it had been taken over for more urgent medical needs and never restarted. Regular outpatient treatment has been given recently at the Mission Hospital itself -24 men and 6 women patients recorded in 1957-58. No regular treatment with sulphones was being given in the government hospitals and dispensaries, the general impression being that the disease was uncommon. The other acid-fast bacillus claimed a great deal of attention: rightly so as tuberculosis was and is by far the most important endemic disease of Aden Colony, whether viewed from the angle of personal suffering, economic loss, or contribution to the Colony's death and morbidity rates.

All medical officers of the department were asked to refer cases of leprosy or suspected leprosy to the laboratory of the Civil Hospital where details of history and physical examination were noted and examination of scrapings from the most likely-looking lesions made. The patients were then started on the standard course of DDS ("Avlosulphone") and told to attend twice a week as outpatients.

The majority came from the large outpatient department of the Civil Hospital (total new attendances per annum c. 20,000): a few from the Colony's other four dispensaries: a few sent by colleagues for medical, dermatological, or laboratory consultation: and a few spotted in the streets of the town and urged to attend hospital.

The resultant "Leprosy Clinic" has now been in action (April 1958) for $26 \frac{1}{2}$ months and 126 persons have been seen and offered treatment. However, for $11 \frac{1}{2}$ months, other duties and the interruption of a leave reduced the clinic's activities to a minimum, only 15 cases being recorded. The other 111 were seen within 15 months, making an average of seven new cases of leprosy presented per month.

Distribution of cases: the places of origin of the patients and the presumed origins of their infections were as follows:

$\begin{array}{llrr}\text { Yemen . . . } & \ldots & 76 & 60 \% \\ \text { Western Protectorate } & . & 33 & 26 \% \\ \text { Eastern Protectorate } & \ldots & 5 & 4 \% \\ \text { Aden Colony } \ldots & \ldots & 5 & 4 \% \\ \text { Unrecorded } \ldots & \ldots & 5 & 4 \%\end{array}$

Of the above only eight were women (four Yemen, two W.A.P., two Colony). 
It is impossible to disentangle from the circumstances which determine attendance, such as transport facilities, the factor of the local incidence of the disease. Nevertheless, it is clear that the vast majority of those with leprosy come from outside the Colony and most of them from the neighbouring country for the health of the subjects of which we in Aden have no responsibility and over which we have no control whatever. Of the 33 seen from the Western Aden Protectorate, 11 came from the close-by sultanate of Lahej, where there is an accessible focus of disease which should and could be eradicated.

It is doubtful whether all seven of the persons with leprosy now permanently resident in the Colony did acquire the disease here.

The small proportion of women and children is partly due to the reluctance of the women to come to hospital, but mostly because the immigrant labourers from the Yemen leave their families at home when they come down to Aden, either for work or medical attention.

\section{Types of Leprosy}

$\begin{array}{llll}\text { Tuberculoid .. } & \ldots & \ldots & 69 \\ \text { Intermediate . . } & \ldots & \ldots & 24 \\ \text { Lepromatous } & \ldots & \ldots & 19 \\ \text { Unrecorded .. } & \ldots & \ldots & 14\end{array}$

There was no noticeable relationship between place of origin and type of leprosy. What was remarkable was that there were no completely incapacitated patients, and none with gross ulceration. It may be that such advanced cases never succeed in reaching Aden, but advanced cases of all other varieties of chronic disease, e.g., tuberculosis and cirrhosis of liver, arrive here in small numbers continually. One concludes that the resistance of the Arab to the disease is high and that in a large proportion of cases the defences of the body arrest its extension and the disease burns itself out. However, in Yemen, advanced cases do exist in plenty according to Hayyat (1958).

\section{Examination for M. leprae}

$$
\begin{aligned}
& \begin{array}{llll}
M . & \text { leprae found } \quad \ldots & \ldots & 62
\end{array} \\
& \text { M. leprae not found } \quad \text {. } \quad 39 \\
& \begin{array}{llll}
\text { Not examined } \quad . & \text {. } & 25
\end{array}
\end{aligned}
$$

Acid-fast bacilli were sought in scrapings taken from the nose and from the two other most likely-looking sites: nodules, edges of leprides, ear-lobes, etc. Some were omitted owing to pressure of other work and sometimes patients who had been examined clinically failed to return to the laboratory for examination of scrapings.

\section{Treatment}

The standard course recommended by the manufacturers of "Avlosulphone" was used. Patients were told to come twice a week 
to get their tablets, and when they showed that they could be relied on to come regularly, they were given supplies for a month at a time. and warned to return at any sign of reaction. The scheme was on the whole not a success, as can be seen from the following table:

Referred elsewhere, i.e., to Protectorate Health Services or other Colony dispensaries $\quad \ldots \quad 23$

Did not return for any treatment $\quad \ldots \quad \ldots \quad 36$

Attended for less than one month .. . . 31

Attended for one to six months only .. $\quad . . \quad 24$

Attended for more than six months .. $\quad . . \quad 10$

Completed course of $1 \frac{1}{2}$ to 2 years .. $\quad . . \quad 2$

Two patients developed severe reactions to the drug, with anaemia, and fever during the treatment: both recovered, though slowly, when admitted to hospital and deprived of the medicine. They were able to continue on a reduced dose.

\section{Social Circumstances}

Most of these patients are very poor indeed and while in Aden exist by begging; they are illiterate labourers from the Yemen or the Aden Protectorates, living on a diet barely sufficient in calories or protein, and subject to other diseases too, such as malaria and schistosomiasis. A fair proportion might be able to do light manual labour in their own villages but the progress of the disease has driven them to seek medical aid in Aden where they cannot compete with their fitter countrymen. The doctor's offer of a two year course of treatment with tablets is of very little use to them: they try the unimpressive bi-weekly doses for a short time and then finding no noticeable relief, give up attending the clinic. There is no way of following up such defaulters, even if we had the staff, as they have no permanent addresses in the Colony and sleep in the streets. A very few decide to make a real job of mendicancy in Aden-probably an income of a shilling a day is enough to keep body and soul together (3/- a day provides a nutritionally adequate diet in Aden, and I have lived on it for a month myself). They can then continue treatment, and one cheerful mild lepromatous lad of 16 or so has persisted long enough to feel and know the improvement in his health. A few continue begging without returning for the tablets, but most-it is impossible to say how many-go home disappointed.

There have been, however, a dozen or so attending regularly or irregularly who were in reasonable economic circumstances from the start: these are the ones who will also probably persist in the future with treatment. A broker, a merchant, a clerk, a student, a housewife living near the hospital-they have done well and the disease has been arrested at least: with the assistance of a health visitor, they could probably all be persuaded to continue for the full period of time desirable-but they need "chasing". 
There seems to be no rejection of the case of leprosy by society as a whole whether in the town or in the villages of the Protectorates or the Yemen: no attempt is made to isolate them and there is little or no "leprophobia".

\section{Western Protectorate}

Patients from this area were sent back to their villages and arrangements for their treatment left in the hands of the Protectorate Health Service, through their Health Units. These are staffed by trained orderlies who can issue the DDS tablets regularly, and 63 patients were registered in 1956.

\section{Eastern Protectorate}

A similar arrangement exists but there is also a small leprosarium in Mukalla housing about 50 sufferers, at public expense.

\section{The Yemen}

Sulphone treatment was instituted a few years ago at Sana and Taiz hospitals but there must be far more leprosy than can be dealt with by these two centres in the rest of the country.

\section{Conclusions}

Leprosy is not a major public health problem in the Colony, but there are at any one time probably between 30 and 60 cases at large, most of them infectious. With the assistance of a health visitor it would not be difficult to get adequate treatment for any who live permanently in the Colony: and as these are living in houses and are likely to be in close contact with children, this is important not only for themselves but for the prevention of spread. As the rest live and sleep for the most part in the open air and are unlikely to be in close contact with children, the danger of spread is slight: the problem here is one of the tragedy of the individual-cure is available but cannot be used so long as there is a lack of supervisory health personnel. The patient makes the long journey from a remote village to the hospital in hope, but is apt to go back in despair when he finds that prolonged treatment is necessary.

\section{Summary}

A description is given of an attempt to assess the problem of leprosy in Aden Colony, and initiate treatment.

My thanks are due to the Director of Medical Services, Aden, for permission to publish this paper.

\section{Reference}

Hayyat, M. U. Late WHO Adviser in Public Health to the Government of the Yemen. Personal communication. 